\title{
Diálogo de saberes para uma racionalidade socioambiental no território centro-norte mato-grossense: possibilidade via educação ambiental?
}

A crise socioambiental configurou-se mundialmente em meados do século $X X$ devido à consolidação da sociedade urbano-industrial e dos avanços da ciência moderna, pautada pela racionalidade técnico-científica instrumentalizada aplicada para atender o modelo antropocêntrico de dominação da natureza para expansão capitalista. Essa crise global manifesta-se localmente no território centro-norte no estado de Mato Grosso a partir da expansão do capitalismo, a qual tomou forma, em especial na década de 1970, por meio das políticas desenvolvimentistas de integração nacional à Amazônia. A ocupação do espaço - por meio da colonização público-privada que atraiu o interesse de grandes grupos nacionais e internacionais -modificou a dinâmica territorial, movimentação de fauna e flora e também das populações seja das preexistentes no território, seja das populações migrantes em suas diferentes situações. Tal processo ocorreu de modo rápido e intenso, gerando desequilíbrios socioambientais na terra, na água, no ar, na biodiversidade e nas culturas preexistentes no território devido à inserçãa da Amazônia Legal - como região funcional - no contexto do capitalismo globalmente estruturado, perpetuando localmente os efeitos da crise socioambiental global. Dessa forma, o artigo em questão objetiva compreender como a Educação Ambiental no encontro com o diálogo de saberes e culturas pode produzir uma racionalidade socioambiental na região centro-norte mato-grossense. Por meio de revisão bibliográfica, o estudo revelou que, embora exista uma fragilidade das práticas de Educação Ambiental e/ou adoção de atividades pontuais e não contextualizadas - o que não explicita as relações mercantilizadoras e insustentáveis existentes no modelo de sociedade vigente - quando trabalhado de forma crítica e dialógica, tal modelo promove a compreensão ampliada das relações complexas entre sociedade e natureza. Ademais, a Educação Ambiental no encontro com o diálogo de saberes científicos com os saberes culturalmente construídos por populações tradicionais (indígenas e não indígenas), os quais coevoluem com a natureza, possibilita a construção da racionalidade socioambiental que subsidia uma compreensão que aproxima as ciências da vida, da natureza e da sociedade e é pautada em princípios éticos, democráticos, justos e ecologicamente sustentáveis.

Palavras-chave: Educação Ambiental; Diálogo de Saberes; Racionalidade Socioambiental.

\section{Dialogue between knowledges for a social-environmental rationality in north central territory of Mato Grosso: is it a possibility via environmental education?}

\begin{abstract}
The socio-environmental crisis had its structure established worldwide in the middle of twentieth century due to the consolidation of urban-industrial society and the advances of modern science, which is ruled by applied technical-scientific rationality applied in order to correspond to the the anthropocentric model of domination of nature for capitalist expansion. This global crisis has its local manifestation in the north central territory in the state of Mato Grosso since the expansion of capitalism, which took shape, especially in the 70's, through the development policies of national integration to the Amazon. The occupation of this space - through public-private colonization that attracted the interest of large national and international groups policies of national integration to the Amazon. The occupation of this space - through public-private colonization that attracted the interest of large national and international groups -
changed the territorial dynamics, movement of fauna and flora and also of populations either the ones pre-existing in the territory or the migrant populations in their different situations. This process occurred in a fast and intense way, generating social and environmental imbalances in the land, water, air, biodiversity and preexisting cultures in the territory due to the deep insertion of the Legal Amazon ? as functional region ? in the context of globally structured capitalism, locally perpetuating the effects of the global socio-environmental crisis. This way, this article aims to understand how Environmental Education in the encounter with the dialogue between knowledges and cultures can produce a social-environmental rationality in the north central region of Mato Grosso. Through a bibliographic review, the study revealed that, although there is a fragility of the practices of Environmental Education and/or adoption of punctua and non-contextualized activities? that does not explain the mercantile and unsustainable relations existing in the current model of society ? when worked in a critical and dialogic way, such model pronos an expanded undersanding of the comp a mode prof scientific knowledges with the knowledges culturally constructed by traditional populations (indigenous and non-indigenous), that are in co-evolution with nature, enables the construction of socio-environmental rationality that subsidizes a science bringing sciences of life, nature and society closer together and has as it basis ethical, democratic, just and ecologically sustainable principles.
\end{abstract}

Keywords: Environmental Education; Dialogue between Knowledges; Social-environmental Rationality.

Topic: Educação Ambiental

Reviewed anonymously in the process of blind peer.
Received: 02/02/2018

Approved: 20/05/2018
Caroline Mari de Oliveira (iD

Universidade do Estado de Mato Grosso, Brasil

http://lattes.cnpq.br/2216258795802689

http://orcid.org/0000-0002-6099-0953

oliveiracaroline29@gmail.com

\section{Aumeri Carlos Bampi}

Universidade do Estado de Mato Grosso, Brasil

http://lattes.cnpq.br/4800812434410023

http://orcid.org/0000-0002-3410-9376

profaumericarlosbampi@gmail.com
Referencing this:

OLIVEIRA, C. M.; BAMPI, A. C.. Diálogo de saberes para uma racionalidade socioambiental no território centro-norte matogrossense: possibilidade via educação ambiental?. Revista IberoAmericana de Ciências Ambientais, v.9, n.1, p.164-187, 2018. DOI: http://doi.org/10.6008/CBPC2179-6858.2018.001.0012 


\section{INTRODUÇÃO}

A década de 1970 caracterizou-se por um contexto histórico de produção, marcado pela mundialização do capital global, das transformações sociais resultantes da devastadora crise estrutural do capital e das soluções encaminhadas pela ordem hegemônica à crise, de modo a legitimar estratégias de regulação e reestruturação das relações econômicas, políticas e sociais capitalistas. Esse contexto, segundo Harvey (2009), produziu um desenvolvimento geográfico desigual, baseado na territorialização, desterritorialização e reterritorialização contínua do capital em diferentes espaços a partir da racionalidade técnica-científica-econômica que orienta as relações insustentáveis de apropriação privada e concentradora na exploração e uso dos recursos naturais e apropriação desigual da terra.

Nesse mesmo período, também em âmbito global, evidenciaram-se as problemáticas da crise socioambiental que não se tratou apenas de uma crise ecológica, mas da racionalidade técnica-científica associada ao sociometabolismo do capital. Chesnais (2008) explicita que as raízes da crise ecológica e da crise econômica são as mesmas, pois se remetem à natureza do capital e à superprodução capitalista que devem crescer desmedidamente, reproduzir-se com lucro sem fim e sem limites. Consequentemente, esse momento que marcou a fase da mundialização e financeirização do capital aprofundou a crise ecológica e provoca ainda graves efeitos sociais em nível mundial devido à utilização de fontes não renováveis, aceleração das emissões de gases do efeito estufa e do esgotamento dos recursos naturais em longo prazo, como o solo, por exemplo. Identifica-se, portanto, a questão socioambiental no centro das contradições do mundo moderno, afinal, a ideia de progresso e de desenvolvimento é sinônimo de dominação da natureza de forma globalizada para a continuidade da superacumulação de capital. Nesse sentido, Leff (2006) aponta que a "crise socioambiental não é apenas uma crise ecológica, mas é a crise da razão e da civilização". Portanto, a percepção da crise socioambiental, a partir da década de 1970, possibilitou o questionamento das contradições da razão técnica-científica moderna com relação à fragmentação do ser da natureza, bem como da instrumentalização da ciência moderna aplicada aos interesses do capital (SILVA, 2015).

Segundo Porto-Gonçalves (2012), nas décadas de 1960/70, antes do período de globalização neoliberal, implantou-se um modelo de desenvolvimento da sociedade urbana-industrial pautado na ideia da racionalidade moderna-colonial para os países desenvolverem-se e acumularem riquezas, de modo a integrarem-se ao sistema econômico-produtivo internacional. Para tanto, era necessária a dominação da natureza, a qual é justamente o "[...] cerne da questão ambiental”. É notório relacionar essa ideia à história do Brasil, no qual, justamente na década de 1970, vivenciava-se o auge da ditadura civil-militar. Em virtude dessa forma de governo, manifestaram-se nos discursos governamentais ideias marcadamente desenvolvimentistas associadas à dominação da natureza para expansão do capital que davam continuidade ao ideário desenvolvido na década de 1930, que permeou o governo de Getúlio Vargas com a Marcha para o Oeste, programa político do Estado Novo a fim de modernizar o país por meio da integração entre as fronteiras políticas com as fronteiras econômicas (VELHO, 2009). 
Nesse sentido, a ideologia que marcou os governos brasileiros foi a de desenvolvimento econômico e de afirmação do "Estado sobre a nação (ou as nações, ou as tribos [...] para adaptar-se ao modelo capitalista internacional" (SANTOS et al., 2014). Os discursos ufanistas dos colonizadores privados e dos governos da época ansiavam pelo progresso e pelo desenvolvimento da nação nos moldes do mercado global. Desse desenvolvimento, pode-se compreender que a expansão do capitalismo na Amazônia pelo "integrar para não entregar" foi realizada de modo totalmente acrítico e associado à degradação socioambiental, contribuindo para o aprofundamento da crise socioambiental no contexto nacional e local na Amazônia norte matogrossense.

Merece destaque, para a análise da crise socioambiental na Amazônia norte mato-grossense, a região centro-norte, que está localizada no bioma amazônico (SEPLAN-MT, 2017), composta por nove municípios, os quais possuem semelhante histórico de uso e ocupação do território por meio da colonização, em especial, a partir dos anos de 1970. Vale lembrar que o povoamento e a ocupação das regiões CentroOeste e Norte do Brasil ocorreu a partir do ideário traçado na década de 1940, durante o governo de Getúlio Vargas. Esse processo ficou conhecido como Marcha para o Oeste, a qual objetivou a promoção do progresso a partir da exploração e do uso de recursos naturais para gerar crescimento econômico e integração da região ao território nacional (MARTINS, 1997; CASTRO, 2002).

Os municípios e as cidades dessa região surgiram "na floresta" ${ }^{1}$ " por meio da dinâmica territorial resultante das políticas econômicas desenvolvimentistas e integracionistas do governo militar para efetivar a integração da Amazônia ao território nacional. Nesse sentido, prevaleceu a implantação de projetos de desenvolvimento econômico, saberes e práticas articulados à lógica da apropriação privada dos bens de uso comum como os recursos naturais, gerando problemas socioambientais ligados aos recentes processos de dinamização territorial.

Nesses espaços, seguiu-se a lógica de crescimento por meio da redefinição das relações entre os homens e o uso e a ocupação do território pela via da exploração dos recursos naturais e da negação de populações pré-existentes nesses territórios. Tais ações ocorreram perante os condicionantes nacionais e internacionais do processo produtivo e reprodutivo do capital favorecido, o que Santos (2006) denomina de meio técnico-científico-informacional.

Segundo Santos e Silveira (2014), o meio técnico-científico-informacional é o terceiro período da história do território brasileiro, durante o qual a modernização da agricultura, que pressupõe a nova utilização agrícola do tempo e da terra e a reinvenção da natureza, constituiu-se um dos condicionantes para a formação da fronteira agrícola no norte mato-grossense. Esse período data a partir da década de 1970 resultado de um processo iniciado no pós II Guerra Mundial, quando era necessário expandir o capital de modo globalizado. A dificuldade que se vislumbrava no território brasileiro para atender a

\footnotetext{
${ }^{1}$ As cidades na floresta são "[...] aquelas que tendem a se articular principalmente às demandas externas da região, fazendo da floresta um elemento de pouca integração aos novos valores da vida urbana, sendo mesmo sua negação, e tida principalmente como espaço de exploração econômica" (JúNIOR, 2013).
} 
internacionalização do capital resultava da ausência de uma rede nacional de transportes para integrar um país com dimensões continentais.

Assim, os progressos da ciência e tecnologia e a circulação de informações, com a globalização, fizeram o Brasil desdobrar seu território. Buscou-se tornar viável ao enraizamento de grandes capitais que geraram, via fartos subsídios públicos² (OLIVEIRA, 2005), condições materiais e imateriais para aumentar a especialização e a modernização do trabalho no território nacional, inclusive com a regulação do Estado por meio dos governos ditatoriais, ou seja, é uma nova divisão territorial do trabalho, atendendo especificidades da produção ao mercado mundial. Para tanto, ocuparam áreas até então periféricas, remodelaram diversas regiões, ampliaram a descentralização industrial localizada até então na Região Concentrada ${ }^{3}$ do país, fazendo despontar novos belts modernos e novos fronts na agricultura sobre sistemas ecológicos tropicais.

Tal situação, contudo, não se fez abruptamente, dada a necessidade de se criar um conjunto de condições propícias por intermédio do desenvolvimento de pesquisas de adaptação da agricultura temperada à situação da floresta tropical ou em zonas de savanas, que foram sendo adulteradas a partir da ótica das "vocações regionais" e interiorização do desenvolvimento, ligando as fronteiras políticas e econômicas por meio de critérios políticos e administrativos criados pelo Estado para inserção do país na era dos monopólios, internacionalização e mundialização do capital (OLIVEIRA, 2005; VELHO, 2009).

Assim, a interiorização e a integração nacionais explicam-se a partir dos projetos de modernização, implantação de políticas públicas de planejamento regional, a partir dos governos pós-Vargas e do processo de uso e ocupação da Amazônia, sendo a mercadoria principal a apropriação privada da terra e o apoderamento das riquezas naturais da Amazônia Legal, gerando uma nova lógica de valorização e ocupação dos "espaços vazios" da região (OLIVEIRA, 2005). Santos e Silveira (2014) afirmam que, nesse período, alargaram-se os contextos, foi imposta mais cooperação entre pontos distintos e distantes do território, a circulação ganhou importância fundamental nesse processo; porém, as novas vocações regionais são repetidas vezes "[...] produtoras da alienação, pela pressão da ordem global sobre as populações locais" (SANTOS; SILVEIRA, 2014).

O movimento nesse espaço particular seguiu uma lógica nacional integrada à internacional que era viabilizada por uma política de povoamento e produção agrícola, em detrimento das populações e produções preexistentes, associadas a um conjunto de infraestruturas que permitiram o processo de uso e ocupação do território. Nesse espaço, juntamente com as empresas colonizadoras, estabeleceram-se também as agências bancárias e as instituições governamentais como Superintendência do Desenvolvimento da Amazônia (SUDAM), Banco da Amazônia S.A. (BASA), Polo da Amazônia (POLOAMAZÔNIA) e Banco do Brasil, entidades

\footnotetext{
${ }^{2}$ Segundo Oliveira (2005, p. 68-69), esses subsídios políticos perpassavam um conjunto de políticas, tais como a transformação da Superintendência do Plano de Valorização Econômica da Amazônia SPVEA em SUDAM; abertura de eixos rodoviários; incentivos fiscais e creditícios; implantação de grandes projetos agropecuários e agroindustriais; implantação dos projetos de colonização privados e públicos; acesso de grupos econômicos nacionais e ou internacionais aos recursos minerais da região; implementação de programas de desenvolvimento como Programa de Integração Nacional (PIN) visando a um grande sistema viário federal, que inclui a abertura de duas importantes rodovias na Amazônia: Transamazônica: BR-230 e Cuiabá-Santarém: BR-163, sendo que esta última motivou o processo de ocupação e escoamento da produção para exportação; e a criação de programas de polos de desenvolvimento com capital nacional e estrangeiro, como: Poloamazônia; Polocentro; Polonoroeste e Prodeagro.

${ }^{3}$ Região Concentrada era constituída por estados do Rio de Janeiro, Espírito Santo, Minas Gerais, São Paulo, Paraná, Santa Catarina e Rio Grande do Sul (SANTOS, SILVEIRA, 2014).
} 
que possibilitaram a inserção de meios técnicos-científicos-informacionais para integração da Amazônia ao capitalismo nacional-internacional.

As políticas desenvolvimentistas do período supracitado não levaram em conta as possíveis consequências socioambientais que geraram intensa degradação socioambiental. Desmatamentos, queimadas, movimentos de fauna e flora e de humanos, descontrole na extração e comércio madeireiro, mercantilização de recursos naturais, como a água, solo, etc., implantação de grandes empreendimentos, monoculturas e pastagens, disputas territoriais, invasão de terras indígenas que ocorreram em função do avanço no capitalismo na fronteira agrícola (ARANTES et al., 2017).

A transformação rápida e não harmoniosa desse território provocou a redução de populações nativas em função da chegada do novo, do "moderno", o qual subjugou as diversas territorialidades preexistentes. Os saberes e a diversidade de enfoques epistêmicos, construídos em uma relação de coexistência com a natureza, foram negados ou negligenciados em virtude da inserção de uma racionalidade técnica-científica utilitarista e econômica insustentável que configurou histórica e localmente a crise socioambiental. Contraditoriamente, enquanto no território norte mato-grossense instalavam-se as condições para um futuro acirramento da crise socioambiental, no âmbito global discutiam-se os padrões dominantes de civilização que originaram a crise socioambiental (PORTO-GONÇALVES, 2012).

Este artigo de revisão teórica é um breve recorte da pesquisa de doutorado, em andamento, a qual tem como objeto de estudo o diálogo entre saberes ambientais e a diversidade cultural coexistente no território centro-norte no Estado de Mato Grosso. O lócus de análise situa-se no bioma amazônico, que é marcado por complexas relações entre homens e natureza inseridas no pós-1970, as quais, diferentemente das racionalidades nativas, replicam localmente a crise socioambiental global gerada pelo modelo urbanoindustrial que sustenta o modo de produção capitalista.

Dos fenômenos que influenciaram a forma de desenvolvimento dessa região, destaca-se o avanço do capitalismo no contexto amazônico por meio do histórico de uso e ocupação do território, resultantes das políticas de integração nacional, formação da fronteira agrícola e da dinâmica territorial de diferentes grupos sociais nesse espaço. Desse processo, gerou-se a crise socioambiental local, conectada à crise do modelo urbano-industrial global, identificada localmente por meio do desmatamento civilizador, da intensa exploração e mercantilização de recursos naturais, da dizimação da floresta amazônica para a implantação de grandes monoculturas e pastagens, de disputas territoriais e formações das cidades na floresta, da implantação de ciência e tecnologia para a transformação rápida e não harmoniosa dos ecossistemas, da perda drástica e redução da diversidade ecológica, pelo confinamento de culturas nativas e dos encontros e desencontros entre homens e natureza. Assim há a negação da outridade, ou seja, a negação da diversidade de povos preexistentes e de suas maneiras de viver e saber construídos em relação intrínseca com, na/da natureza e da própria natureza primitiva, forjada também pela coevolução com os homens nativos e sociedades preexistentes.

Portanto, por meio do referencial teórico utilizado neste estudo, problematiza-se: é possível que a Educação Ambiental no encontro com o diálogo entre culturas e saberes possibilite caminhos alternativos à 
construção de uma racionalidade socioambiental, pautados na justiça social, sustentabilidade e na diversidade de modos de ser, saber e existir coexistentes no território centro-norte mato-grossense?

\section{METODOLOGIA}

Para responder à problemática proposta por esta pesquisa, adotou-se a abordagem qualitativa a partir do método dialético ${ }^{4}$, o qual permite compreender a relação natureza e sociedade, tecendo reflexões articuladas às questões socioambientais do local desta pesquisa ao âmbito global que é analisado em articulação com o contexto histórico da fase da mundialização do capital global, das transformações sociais resultantes de devastadora crise estrutural e ambiental, mais visíveis a partir da década de 1970.

Este estudo, de caráter exploratório, apoiou-se na pesquisa bibliográfica de fontes teóricas, pois se entende, a partir de Saviani (2004, p. 38), que as fontes bibliográficas indicam "[...] a base, o ponto de apoio, o repositório dos elementos que definem os fenômenos cujas características se busca compreender [...]". Assim, as fontes não são naturais, mas sim uma produção humana embasada na construção da história.

Portanto, pautou-se na revisão bibliográfica dos pressupostos teóricos de Milton Santos, Enrique Leff, Boaventura de Souza Santos, Vandana Shiva, Aníbal Quijano, Arturo Escobar, Marília Tozoni-Reis, Ana Tereza Reis da Silva, dentre outros nomes, os quais lançam luz para compreender a questão socioambiental em uma perspectiva holística e dialética da relação entre seres humanos e natureza. Ao mesmo tempo, analisam a perspectiva da Educação Ambiental como forma de religação com saberes diversos para construção de uma racionalidade socioambiental que respeite à justiça social e à sustentabilidade, da qual emerge de uma problemática que envolve questões ecológicas, econômicas, sociais, políticas e culturais.

\section{Área de Estudo}

Optou-se por articular o referencial teórico às observações da complexidade socioambiental existente na região centro-norte de Mato Grosso devido ao seu processo histórico recente, a partir da década de 1970. No âmbito do período militar, quando foram implementadas políticas governamentais para efetivar a integração da Amazônia, destacam-se como principais obras a construção de eixos rodoviários, como a BR163 (que liga Cuiabá/MT-Santarém/PA), principal eixo de escoamento da produção agropecuária da região e interligação do fluxo colonizatório contemporâneo que chegou entre meados das décadas de 1970 e 1990, substanciado por um modelo de colonização e desenvolvimento capitalista na Amazônia Legal, de forma a viabilizar as condições do capital privado por meio da expansão de áreas produtivas para abastecimento interno e exportação.

A região norte de Mato Grosso é composta por 55 municípios, agrupados em oito microrregiões onde se concentra mais da metade da produção de grãos do estado e grande parte da atividade pecuária do estado. Contudo, a riqueza gerada por meio dessa produção não é uniformemente dividida, assumindo

\footnotetext{
${ }^{4}$ De caráter materialista (porque os homens constroem e organizam-se em sociedade para a (re)produção da vida) e histórico (porque estes se organizam através da história) (TOZONI-REIS, 2008).
} 
efeitos colaterais como a violação da justiça socioambiental que é preterida por uma racionalidade de dominação e degradação socioambiental em todo território norte mato-grossense.

Dessas microrregiões, optou-se como lócus de análise o território da região centro-norte, constituído por nove municípios, quais sejam: Vera, Cláudia, Feliz Natal, Itaúba, Marcelândia, Nova Ubiratã, Santa Carmem, Sinop e União do Sul. O bioma predominante na região é amazônico e localiza-se nas coordenadas geográficas: latitude de 103'S e 13 40’S - longitude de 53 10’ W e 5620’ W. A região é drenada pela Bacia do Rio Amazonas, a sub-bacia principal é dos Rios Tapajós e Xingu e as sub-bacias secundárias são dos Rios Teles Pires e Xingu (IBGE, 2011; SEPLAN-MT, 2017). A constituição desses municípios resulta de processos econômicos de exploração extrativista vegetal (madeira), produção pecuária e, principalmente, da inserção da agricultura de larga escala aplicada à intensa modificação do uso do solo, que provocou fortes impactos econômicos, culturais e socioambientais nesta região de estudo.

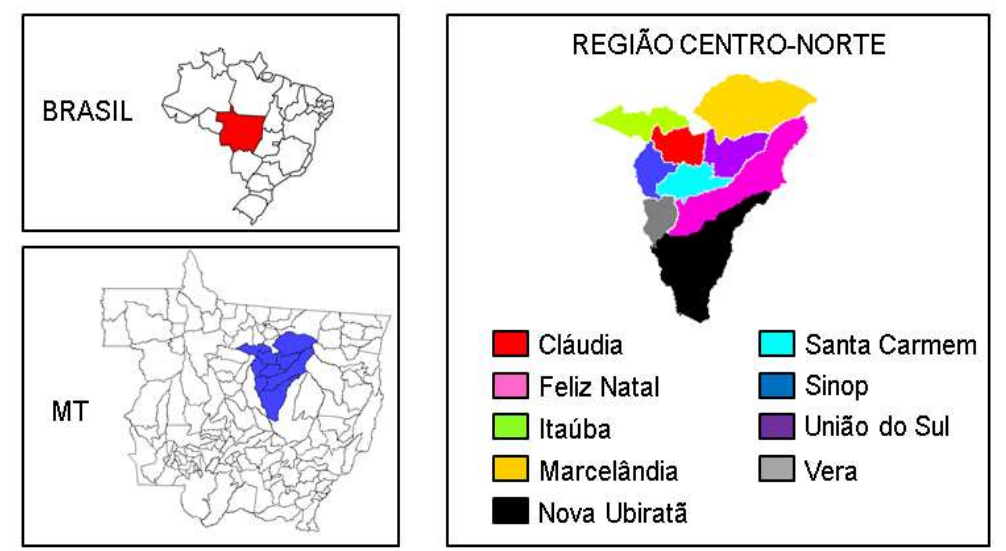

Figura 1: Localização dos municípios da região Centro-Norte - MT. Fonte: SEPLAN-MT (2017).

O território centro-norte mato-grossense, assim como todo estado de Mato Grosso, é composto por um mosaico cultural. No caso da região escolhida para o estudo, esse mosaico cultural foi constituído inicialmente por comunidades preexistentes, em especial, formado pelas etnias indígenas Kayabi; Kisêdjê e Ikpeng. Depois, pela chegada de exploradores e seringueiros e, mais tarde, pela chegada de migrantes de outras regiões brasileiras, principalmente, da região Sul do país, em suas diferentes situações, tais como os camponeses - os quais foram excluídos do processo de modernização da agricultura - e empresários do campo e do setor madeireiro - que vislumbravam nessas condições meios para acumulação de terras e riquezas.

Vale ressaltar que a modernização da agricultura brasileira ocorreu com grande apoio do Estado brasileiro, principalmente, por meio das conjunturas políticas dos governos das décadas de 1960, 1970 e 1980, 1990 e 2000 que possibilitaram “[...] as condições para a internacionalização da produção de máquinas e insumos para a agricultura, um sistema de pesquisa e extensão voltado para impulsionar o processo de modernização e as condições financeiras para viabilizar este processo" (ALENTEJANO, 2012).

Mais recentemente, a partir da década de 1990, nessa região instalaram-se as instituições de ensino e pesquisa que possibilitaram o movimento de diversas pessoas no referido território, bem como a produção 
e difusão de conhecimentos técnico-científicos para o progresso e o desenvolvimento da região, pautados na modernização da agricultura a serviço do mercado globalizado.

Esse território mantém, portanto, a copresença de diferentes grupos sociais, demonstrados na figura abaixo, os quais possuem suas territorialidades marcadas pela diversidade cultural e por organizações socioeconômicas que materializam as condições "modernizadoras" e integradoras da região local a funcionalidades da demanda internacional. Os diferentes grupos sociais (re)produzem seus saberes ambientais que dinamizam e marcam a complexidade socioambiental desse território que podem ou não dialogar a fim de efetivar seus diversos interesses.

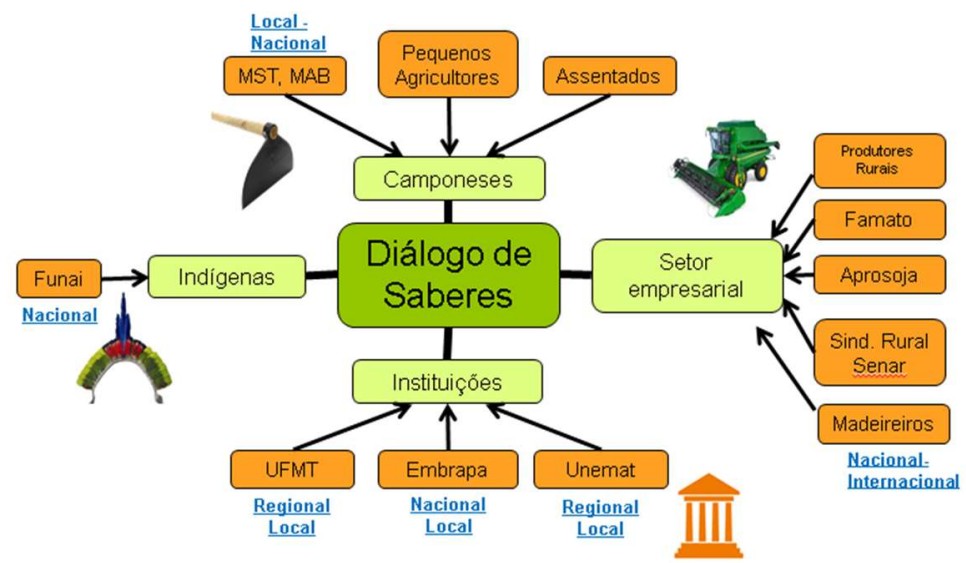

Figura 2: Representação dos grupos sociais coexistentes na região centro-norte de Mato Grosso. Fonte: Silveira et al. (2012).

\section{DISCUSSÃO TEÓRICA}

\section{Educação ambiental no encontro com o diálogo de saberes e culturas para construção da racionalidade socioambiental}

A crise socioambiental global emerge dos efeitos da Revolução urbana-industrial, no século XVIII, momento em que a sociedade urbana-industrial ocidental organizou a economia e o conhecimento técnicocientífico voltado à produção e consumo de modo intenso, desequilibrando a relação entre os homens e os sistemas ecológicos. Porto-Gonçalves (2012) aponta que essa revolução possibilitou o intenso processo de acumulação de capital por meio da transformação de matéria e energia contida nos ecossistemas em ilhas de recursos geologicamente armazenados (petróleo, gás, jazidas, minerais etc.). Esses processos provocaram a insustentabilidade socioambiental propagando a mercantilização do que era produzido, do trabalho assalariado e, sobretudo, dos modos de produção.

A sociedade urbana-industrial revela-se antropocêntrica em virtude da ruptura entre o homem e natureza, dominando a ideia de objeto=natureza. Nesse processo, a ciência e a técnica tornaram-se instrumentos hegemônicos para o domínio e incessante modificação dos espaços e dos recursos naturais. Contudo, para atender a expansão do capitalismo em razão, esse modelo de sociedade propiciou diversos sinais de esgotamento e de degradação dos ecossistemas em escala global. Essa questão revela que a crise socioambiental não é apenas ecológica, mas da civilização pautada sob o paradigma da sociedade urbanaindustrial (FLORIANI, 2010). Assim, identifica-se a questão socioambiental no centro das contradições do 
mundo moderno. Afinal, a ideia de progresso e de desenvolvimento é sinônimo de dominação da natureza, excluindo toda a biodiversidade existente no planeta, colocando em xeque os direitos dos povos do futuro a viverem em um ambiente justo, equilibrado e ecologicamente sustentável.

Segundo Leff (2006), a racionalidade econômica produtiva consiste em "um modo de produção fundado no consumo destrutivo da natureza que vai degradando o ordenamento ecológico do planeta Terra e minando suas próprias condições de sustentabilidade". A gênese dessa problemática socioambiental ocorre por meio da dinâmica do modo de produção capitalista que está em constante expansão por meio de meios técnicos e científicos gerados por uma racionalidade econômica que objetiva "maximizar os lucros e os excedentes econômicos em curto prazo, em uma ordem mundial econômica marcada pela desigualdade entre nações e classes sociais" (2006).

A crise socioambiental manifesta-se localmente conectada com a crise ambiental global de modo a replicar o paradigma técnico-científico do modelo urbano-industrial por meio da inserção do capitalismo na Amazônia. O processo de uso e ocupação do território centro-norte mato-grossense, no contexto das políticas desenvolvimentistas pós-64, do "integrar para não entregar", possibilitaram as bases para inserção desse território ao capitalismo mundial.

Bampi (2012) afirma que, na verdade, ocorreu a integração e o "entreguismo" por intermédio da produção, da construção de rodovias, ferrovias, hidrovias, implantação de instrumentos do meio técnicocientífico-informacional que deram suporte ao capital privado por meio da expansão de áreas produtivas para abastecimento interno e exportação de modo a atender as necessidades do sistema econômico e financeiro nacional e internacional, não as necessidades dos povos do país.

Esse processo alterou o conjunto de sistemas complexos de vida que abrigam humanos e não humanos em uma rica sociobiodiversidade existente na Amazônia. Tal território - que compõe diversidade ecológica e social - transformou-se em cenário de inúmeros conflitos, violência, destruição, aniquilação, exploração onde a terra, a água, o bioma tornaram-se mercadorias, local onde ocorreu a exclusão das comunidades preexistentes, cujos habitantes são vistos como entraves para o progresso e desenvolvimento. O território historicamente marcado pela sociobiodiversidade passou a ser ocupado por monoculturas, os humanos subjugados pelo capital, a cultura do supérfluo e do consumo desenfreado em detrimento das culturas e saberes milenares profundamente conhecedores da realidade ecológica, ou seja, a expansão do capital versus dominação do território, do bioma, dos humanos em sua ampla diversidade cultural (BAMPI, 2012).

O progresso e o desenvolvimento, conectados ao paradigma técnico-científico, que embasa a relação antropocêntrica mundial, instalaram-se localmente no espaço centro-norte de Mato Grosso, no bioma amazônico, por meio da exploração predatória de recursos naturais e dos humanos, resultando em uma rápida e intensa degradação social e ambiental, demonstrando a insustentabilidade da expansão do capitalismo na fronteira. Tal processo é totalmente contraditório ao que era apregoado pelo discurso ufanista do Estado e dos operadores locais do capital privado em função da integração ao sistema econômico- 
financeiro internacional que se sobrepõe "a tudo e a todos, a todas as outras, milhares de riquezas deste chão, desta terra, destas vidas e pessoas" (BAMPI, 2012).

Portanto, a problemática socioambiental não é neutra e tampouco alheia a interesses econômicos e sociais. Dentro da perspectiva da racionalidade ocidental, que é abismal, como afirma Santos (2014), a própria questão ambiental é colocada abaixo da linha abissal porque a natureza é tida como objeto a ser dominado, usurpado em suas mais variadas dimensões a fim de atender ou criar demandas mercadológicas. Nesse sistema, povos tradicionais (indígenas e não indígenas) significam atraso à dinâmica capitalista, por serem considerados improdutivos e por não se adequarem no sistema de consumo capitalista. A descoberta do outro no contexto colonial, como ocorreu na segunda metade do século XX no território centro-norte mato-grossense, replicou a lógica da produção ou reconfiguração de relações de subalternidade tal como ocorreu no período de colonização ocidental dos países que hoje constituem a América Latina.

A partir da análise da totalidade real e complexa, síntese de múltiplas determinações sociais, econômicas, culturais e ambientais que acirram a crise socioambiental, emerge a necessidade de uma racionalidade socioambiental, bem como da reconstrução de saberes ambientais e a valorização da diversidade cultural. Tal possibilidade passa pelo caminho da Educação Ambiental articulada ao planejamento de políticas públicas socioambientais como premissas para transformação e ecologização do pensamento ${ }^{5}$.

Nesse sentido, questiona-se a ciência moderna e os avanços tecno-científicos que aprofundaram o fosso entre ser e objeto, reduzindo a relação homem e natureza ao um modelo antropocêntrico, o qual, a partir do conhecimento científico, integrado ao processo econômico e acumulação de capital, preteriu os saberes considerados pela ciência moderna como "tradicionais". Contudo, esses saberes em diálogo com saberes científicos, sem relações de desigualdade ou subjugação, podem construir uma nova racionalidade socioambiental que consiga ecologizar o pensamento, integrar a sociedade e a natureza de modo justo, equitativo, democrático e sustentável, como explicitam Leff (2006), Floriani (2010) e Silva (2015).

Para enfrentar os desafios socioambientais que se fazem presentes em nossa sociedade, faz-se necessário pensar o futuro, repensar a forma de como o homem relaciona-se com a natureza e com diferentes culturas. A negação de culturas é a própria negação das diferentes cosmologias e práticas de coexistência dos homens com a natureza, por intermédio das quais muito se pode aprender por meio do diálogo entre a ciência e a cultura das populações que coevoluem com a natureza.

Segundo Diegues e Arruda (2001), uma das formas de compreender os saberes-fazeres históricos da intervenção humana na natureza e de como são apreendidos pelos indivíduos pela intencionalidade de suas relações sociais é via educação em diálogo com os etnoconhecimentos. Importa, então, estabelecer uma simetria entre diálogo de saberes e técnicas para aperfeiçoar as condições de sustentabilidade nas relações sociedade-natureza.

\footnotetext{
${ }^{5} \mathrm{O}$ termo ecologizar o pensamento inspira-se nas ideias de Edgar Morin quando afirma que é necessária uma revolução do conhecimento de modo a apreender o problema ecológico que atinge o planeta. O problema ecológico é complexo, pois se entrelaça com aspectos culturais, econômicos, políticos e natural. Para tanto, deve-se compreender o problema para além do aspecto local, ou seja, pensar global e agir local e vice-versa, bem como não ignorar e dialogar com outras culturas, artes de viver e conhecimentos de outras populações.
} 
Portanto, é necessário ultrapassar a ciência moderna normal, que descarta os conhecimentos de povos tradicionais, e avançar para o (re)conhecimento da complexidade das relações humanas com o ambiente e que possibilite o diálogo de saberes e culturas, pois as populações que mantêm relações intrínsecas com a natureza possuem um saber-fazer acumulado durante gerações e que foram produzidos para manejo dos ecossistemas, para preservação da biodiversidade local e equilíbrio ecossistêmico (TOLEDO; BARRERA-BASSOLS, 2009). Dessa forma, o diálogo de saberes científicos com os saberes dos povos tradicionais devem refletir sobre as questões socioambientais e desconstruir as racionalidades que levaram o mundo a tamanha crise associada à dominação e degradação da natureza e dos povos que dela dependem em função das monoculturas e da hegemonia do mercado globalizado, como se a ordem natural fosse seguir os desejos/ambições produtivas da ordem econômica do mundo urbano-industrial.

Silva (2015) afirma que a ciência moderna polariza duas cosmologias distintas, sendo uma que carrega a ciência ocidental e que estabelece uma fronteira entre homens e natureza, ser versus objeto, no qual a natureza é externa ao homem e por isso deve-se dominá-la e mercantilizá-la para o desenvolvimento econômico e avanço tecno-científico. A outra cosmologia é praticada por povos tradicionais, como indígenas e não indígenas, sendo a natureza elemento de interdependência. Nesse sentido, "a proteção da natureza encontraria sua melhor expressão na unidade diversa e indivisível das cosmologias tradicionais" (SILVA, 2015).

Portanto, as consequências da crise socioambiental advêm da forma hegemônica e unitária de pensar o mundo, o meio ambiente e os sistemas ecológicos, pautada na racionalidade técnica-científica e economicizadora do mundo moderno. Ademais, essa razão epistemológica fundamenta a prática de exclusão e marginalização da outridade, do diferente do paradigma eurocêntrico, no sentido epistêmico e ontológico, em que "os 'outros' não sabem pensar, ou o seu pensar não é tão sofisticado como" e ontológico no sentido de que "os 'outros' não contam" (SANTOS et al., 2014).

A lógica colonialista e capitalista produziu a linha abissal, colocando abaixo dela os povos tradicionais e suas formas de existências nos diversos contextos do Sul Global ${ }^{6}$, conforme Santos e Meneses (2014). Para o cânone da ciência moderna, os saberes dos povos tradicionais foram colocados abaixo da linha abissal em função do conhecimento técnico-científico que se tornou hegemônico. Contudo, Shiva (2003) explicita que "o saber dominante também é um saber local [...] é apenas a versão globalizada de uma tradição local e provinciana" e colonizadora. Portanto, não é o único saber existente e, para que seja construída uma ciência comprometida com a sociedade, deve travar um diálogo com os saberes da diversidade cultural.

No período inicial de uso e ocupação do território centro-norte mato-grossense, observa-se um processo de sobreposição de saberes-fazeres em função da integração da Amazônia ao mercado nacionalinternacional. Na ocasião, os seres que dinamizam e o território, como as populações nativas e/ou preexistentes, tiveram sua existência e seus saberes sobrepujados em função do novo, da racionalidade

\footnotetext{
${ }^{6}$ Segundo Santos, Meneses e Nunes (2004, p. 2) o Sul Global constitui a "semiperiferia do sistema mundial, o que se veio a chamar Terceiro Mundo, e nós preferimos chamar simplesmente de Sul, um Sul sociológico e não geográfico". "Como símbolo de uma construção imperial, o Sul exprime todas as formas de subordinação a que o sistema capitalista mundial deu origem: expropriação, supressão, silenciamento, diferenciação, desigualdade, etc. O Sul significa a forma de sofrimento humano causado pela modernidade capitalista".
} 
econômica e epistemologicamente fundamentada na herança da colonização moderno-eurocêntrica. A história socioambiental desse território passou a ser contada do ponto de vista do colonizador, do pioneiro, negando, inclusive, o direito dos povos preexistentes a (re)contarem ou compartilharem sua própria história e existência.

Assim, no processo de colonização, os agentes que dela se apropriam observaram os territórios e as populações apropriadas do "ponto zero". Conforme as ideias de Castro-Gomez (2007), não consideraram e não dialogaram com outras formas de relacionar-se com a natureza, ou seja, diferentes modos de existir com e na natureza. Não levaram em conta as formas como as populações do Sul Global produzem seus saberes, seus mapas, a partir de suas visões de mundo dentro das relações espaços-temporais a partir de seus centros de vivência (ESCOBAR, 2016). A hegemonia da racionalidade técnica-científica e os saberes provenientes dessas pessoas expandem-se com o modo de produção capitalista, criando uma fratura abissal no mundo, sendo o Sul e o Norte Global não apenas uma forma territorial, mas também epistêmica e ontológica dando bases para a desigualdade socioambiental a partir da reestruturação socioeconômica e cultural.

A descoberta do outro no contexto colonial envolveu sempre a produção ou reconfiguração de relações de subalternidade, processo este que não se diferenciou no desenvolvimento da fronteira agrícola no contexto amazônico, onde a natureza e os povos "selvagens" foram dominados para fins econômicos e em nome do progresso e desenvolvimento da nação. De acordo com Costa e Loureiro (2013), "negar as origens das civilizações estabelecidas antes da colonização é como uma maldição que atravessa a história da América Latina, pois seus efeitos se manifestam no critério de inferioridade de povos sem história e de Estados sem nação".

Desse processo resultaram os efeitos ecológicos, econômicos e culturais marcadamente assimétricos e desiguais sobre diferentes regiões, populações, classes e grupos sociais, dos quais a região centro-norte integrada ao processo de expansão do capitalismo na fronteira agrícola na segunda metade do século XX não está isenta. Considera-se que são, ainda, poucas as pesquisas que têm se debruçado a compreender a relação entre o moderno uso e ocupação denominada de colonização, modelo de desenvolvimento implantado, construção de saberes ambientais na perspectiva de análise da fratura abismal que esse processo gerou, produzindo a negação territorial e epistêmica da diversidade cultural nativa existente nesse território, que possui profunda relação com a natureza, abrindo perspectivas de modos e saberes de processos integrados entre sociedade-natureza, articulando a um uso e manipulação dos recursos naturais do território de forma integrada e sustentável.

Durante o processo de colonização da região norte do Mato Grosso, localizado no bioma amazônico, migraram muitas famílias do Sul do Brasil, na maioria descendentes de europeus, os quais em suas terras de origem eram excluídos do processo de modernização agrícola e migravam rumo à fronteira agrícola a fim de ocupar os chamados "vazios demográficos". Contudo, ao contrário dos discursos ufanistas e desenvolvimentistas por parte do Estado e das empresas colonizadoras, a região não era um território vazio, pois existiam diversas populações preexistentes que se relacionavam com a natureza de modo integrado. 
Desse processo, observa-se que a colonização e integração nacional foram realizadas mediante a violência e violação da justiça socioambiental.

Oliveira (2005) apresenta que a "colonização no Brasil, particularmente na Amazônia, constituiu-se na alternativa utilizada pelas elites para, ao mesmo tempo, evitar a reforma agrária nas regiões de ocupação antiga, e suprir de mão-de-obra seus projetos econômicos na fronteira". Ainda conforme as ideias de autor, a colonização implantada seguiu a lógica de expropriação essencialmente voltada ao desenvolvimento do capitalismo na região, articulada à mundialização do capital, em que a mercadoria que comandava esse processo na região era a ocupação e a propriedade privada da terra produzindo "frações territoriais distintas na Amazônia brasileira" onde as marcas de "seus donos" prevalecem até os dias atuais, como é o caso do maior município da região abordado por este estudo: Sociedade Imobiliária Noroeste do Paraná7 (Sinop), de Ênio Pipino e João Pedro Moreira de Carvalho.

No território centro-norte mato-grossense foi imposto um modelo de agricultura padronizado em detrimento da diversidade socioambiental. O emprego do meio técnico-científico-informacional, seguindo as orientações da Revolução Verde no que tange à alta produtividade, modernização e incremento de pacotes tecnológicos, com forte indução do Estado para produção mecanizada e insumos para agricultura, sistema de pesquisa e extensão e condições financeiras para viabilizar o processo de uso e ocupação foi voltado à modernização da agricultura. Partindo desse pressuposto, gerou-se a artificialização dos ambientes e a adequação ao padrão mecânico-químico da agricultura moderna por meio do emprego da racionalidade econômica, sobretudo ideológica, que subjugava a racionalidade das populações tradicionais existentes no território (BAMPI, 2012).

A superioridade imposta pelo processo de modernização da agricultura não ocorre apenas à expropriação econômica, mas também aos saberes das populações tradicionais da Amazônia que eram considerados entraves para o progresso do país. A negação, portanto, passa a ser epistemológica e ontológica, seguindo as explicações de Santos e Meneses (2016).

A título de exemplo dessa negação da outridade, tem-se a campanha nacional do governo, por intermédio da SUDAM, para ocupação da Amazônia que dizia: “Chega de lendas, vamos faturar!". Da figura representada abaixo, constata-se a proposta de progresso e desenvolvimento viabilizados por projetos econômicos na Amazônia, estabelecendo a fronteira a ser conquistada para implantações industriais, energéticas e agropecuárias, desconsiderando a presença humana de populações diversas no contexto do amplo território amazônico. Na verdade, o que se revela na propaganda a seguir não é, portanto, o “integrar para não entregar", mas o entreguismo do território e da sociobiodiversidade ao grande capital internacional.

$\mathrm{Na}$ formação territorial da região norte mato-grossense, a fronteira agrícola delimitada subordinou povos, seus saberes, modos de vida a uma lógica monocultural de expansão do capitalismo para essas terras. A diversidade humana existente nesse espaço deu lugar ao modo de vida sulista, já conectada à lógica

\footnotetext{
${ }^{7}$ Considera-se que o nome do município, ao ser constituído, remetendo à empresa colonizadora instalada na região por Ênio Pipino e João Pedro Moreira de Carvalho emprega a negação do que fora encontrado nesse território. Reflete a ideia de "vazio demográfico" ou "terra sem homens para homens sem terra", da constituição de uma cidade na floresta, assim como outras que foram construídas ao longo da BR-163, por exemplo, negando todas as culturas e conhecimentos acerca desse espaço em função da ampliação do capital.
} 
urbano-industrial capitalista. Como exemplo, criaram-se espaços identitários que replicaram o Sul, como os Centros de Tradições Gaúchas (CTGs). É necessário dizer que essa cultura também é portadora de suas raízes históricas e simbólicas importantes a essas identidades, mas nesse espaço torna-se visível a tradição transplantada por meio da colonização, que poderia dialogar com o que já existia.

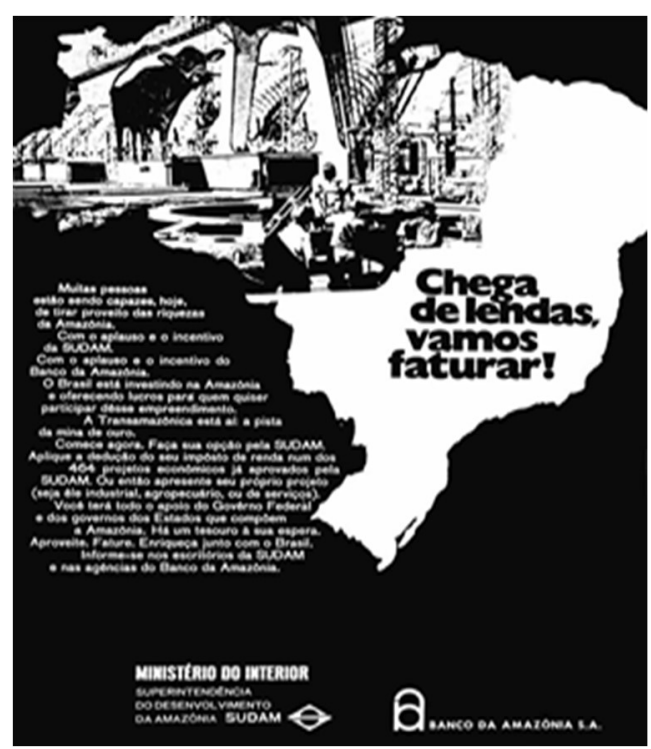

Figura 3: Material publicitário do governo federal para incentivo aos projetos econômicos na Amazônia - 1970. Fonte: Propaganda em Revista (2015).

A questão a ser problematizada é que uma foi estabelecida em detrimento da outra, não dialogando com a existente, não permitindo a ecologia de saberes, como aponta Boaventura de Souza Santos. Nessa questão, o que opera não é o traço identitário do gaúcho sulista, mas a relação instrumentalizada que ele carrega em seu modo de relação com a natureza, pois o sulista "gaúcho", migrante (portador da cultura gaúcha), na verdade, é filho de campesinos, imigrantes europeus, que se dedicaram à agricultura no Sul do país, vivenciando a modernização agrícola, a expulsão do campo, a busca por novas terras em novas colônias e que, posteriormente, foi em busca de terras no Centro-Oeste do país em sintonia com o ideário desenvolvimentista. O germe que essas pessoas carregam é o do "desmatamento civilizador" (BUBLITZ, 2006), pois a ideia de domar a natureza, de subjugá-la é parte importante da ideia de progresso difundida na Europa - de onde provieram seus antepassados no contexto das intensas ondas migratórias europeias do século XIX - essencialmente pelo Positivismo e que se implantou também no Brasil.

Replicou-se nesse território uma herança do colonialismo europeu, trazido pelos migrantes sulistas que, porventura são frutos da colonização europeia no Brasil, especialmente, alemã, italiana, polonesa que se instalaram no Sul do país, a partir do século XIX; no entanto, contraditoriamente, também são sujeitos excluídos do processo de desenvolvimento do capital em suas terras de origem. O processo de colonização implantou o apagamento dos saberes das comunidades tradicionais e indígenas que ocupavam esse espaço, assim como produziu esse apagamento também no interior dos sujeitos migrantes, principalmente, com aqueles que não lograram êxito no processo de colonização do ponto de vista economicista, pois é contada a história política dos vencedores, a história de sucesso econômico, em especial de quem consegue concentrar renda e terra. 
Segundo Leff (2006), a questão ambiental requer um amplo processo de transformação do saber que, em geral, fundamenta-se na racionalidade econômica e dominante, de herança ocidental e que produz a devastação ambiental em diferentes escalas e espaços. No contrafluxo dessa racionalidade, tem-se a racionalidade socioambiental de natureza interdisciplinar que se inscreve a partir da crítica dos modelos racionais científicos, tecnológicos e econômicos para desconstruí-los e passar a internalização do saber ambiental atrelado a novos valores, nova consciência socioambiental e que articula todas as ordens da vida social (cultural, geográfica, políticas, econômicas específicas dos grupos sociais).

A racionalidade ambiental que sustenta o saber ambiental e o desenvolvimento da sustentabilidade exige uma redefinição dos paradigmas econômicos e produtivos de modo a constituir-se em formações econômicas-socioambientais "que incorporem o potencial natural de recursos naturais, os ciclos e tempos ecológicos de regeneração e conservação e os níveis de produtividade ecológica nos processos produtivos" (LEFF, 2006).

Os saberes ambientais e a diversidade de culturas e formas como as populações convivem e cooperam com a natureza possibilitam bases para construir uma racionalidade que considera princípios de desenvolvimento equitativo, sustentável e duradouro, socioambiental. Portanto, conhecer os diferentes sujeitos e vozes do/no território centro-norte de Mato Grosso, na perspectiva da descolonização do pensamento, como pontua Quijano (2005), importa porque esse território não deve ser conhecido apenas como terra da prosperidade e produtividade associada aos monocultivos agropecuários que historicamente se tornaram o modelo dominante no campo, pois, onde são instalados, negligenciam toda e qualquer alteridade/diversidade/outridade presente nos diversos territórios. Nesse processo, ainda que a diversidade cultural venha a ser negada em função das monoculturas produtivas e do ideário que as mantém, nesse território coexistem diferentes grupos sociais, epistemologias, re(ex)istências e lutas emergenciais de grupos considerados do Sul Global que precisam ser (re)conhecidos.

Dessa forma, abre-se um diálogo entre ciência e saber que implica processos de hibridização cultural (MIGNOLO, 2003; MENESES, 2016), revalorizando-se os conhecimentos e os saberes das populações tradicionais produzidos por diferentes culturas em sua coevolução com a natureza.

O saber ambiental propõe a questão da diversidade cultural no conhecimento da realidade, mas também o problema da apropriação de conhecimentos e saberes dentro de diferentes ordens culturais e identidades étnicas [...]. Este produz novas significações sociais, novas formas de subjetividade e de posicionamento ante o mundo. Trata-se de um saber articulado a questão do poder e a produção de sentidos civilizatórios. [...] o saber ambiental problematiza, assim, o conhecimento para refuncionalizar os processos econômicos e tecnológicos, ajustando-os aos objetivos do equilíbrio ecológico, à justiça social e à diversidade cultural. [...] Emerge como um processo de revalorização das identidades culturais, das práticas tradicionais e dos processos produtivos das populações urbanas, camponesas e indígenas, oferece novas perspectivas para a reapropriação subjetiva da realidade; abre um diálogo entre conhecimento e saber no encontro do tradicional e do moderno (LEFF, 2006).

Nesse sentido, a Educação Ambiental no encontro com o diálogo de saberes e da diversidade cultural pode ser uma das formas de construção da ecologia de saberes que propicia as bases para a racionalidade socioambiental que é alternativa ao processo que está posto por meio da sociabilidade do capital. Assim, 
entende-se que a crise socioambiental perdura em uma interface entre os problemas socioambientais com os problemas do conhecimento.

Para efetivarem-se políticas ambientais e a construção da racionalidade socioambiental, deve-se construir uma política de conhecimento que perpassa a dimensão da educação e do diálogo de saberes integrando diferentes culturas e seus saberes provenientes, conforme prevê a Constituição Federal de 1988 (artigos 205 e 225), a Convenção sobre Diversidade Biológica (que resultou da Rio-92), a Lei no 9.795/1999 (que instituiu a Política Nacional de Educação Ambiental no Brasil) e a Lei no 6.040/2007 (que instituiu a Política Nacional de Desenvolvimento Sustentável dos Povos e Comunidades Tradicionais) ${ }^{8}$.

Nesse sentido, a Educação Ambiental, trabalhada de forma crítica e dialógica, lança luz à compreensão da complexidade socioambiental por intermédio da qual se aprenderia sobre e com o meio ambiente de forma contextualizadora com diversas dimensões tais como política, social, econômica, cultural e ambiental, além de aprender a partir do ser do/no e com o mundo, respeitando às diversas identidades que dinamizam as relações entre homens e natureza. Dessa forma, poder-se-ia desconstruir a educação realizada por relações de dominação entre saber-poder ou de relações de autoridade perante a transmissão de um saber certificado (TOZONI-REIS, 2008).

O processo do saber-poder também é criticado por Quijano (2005) sobre a colonialidade do saberpoder e também por Paulo Freire (2005) quando explicita a educação bancária e propõe que a educação seja emancipadora-libertadora. Embora esses autores não tenham se debruçado especificamente ao estudo da Educação Ambiental, lançaram em seus pressupostos teóricos bases para refletir sobre a Educação Ambiental no encontro com o diálogo de saberes ambientais e da diversidade cultural ao reconhecer a outridade, apesar da colonialidade do saber e do poder que invisibiliza populações e seus saberes no Sul Global. A colonialidade do saber implica na desconsideração ou combate de outras formas de produzir conhecimentos que não sejam as produzidas pelas fronteiras hegemônicas.

São essas perspectivas de educação e relação entre saber-poder que se encontram com as orientações de Leff (2006), Jacobi (2005) e Tozoni-Reis (2008) sobre a Educação Ambiental de forma crítica e dialógica para construir uma nova racionalidade que permite ser, pensar e atuar no mundo dialogando com as identidades e diferenças, no qual consolida os sujeitos sociais em cidadãos. É saber ser com a outridade dentro dos princípios epistemológicos e pedagógicos para apreender a complexidade socioambiental.

Então a educação deve preparar novas gerações não apenas para que aceitem a incerteza em face do desastre ecológico; ela deve preparar também novas mentalidades, capazes de compreender as complexas inter-relações entre os processos objetivos e subjetivos que constituem seus mundos de vida, para gerar habilidades inovadoras tendo em vista a construção do inédito. Trata-se de uma educação que permite que os indivíduos se preparem para a construção de uma nova racionalidade; não para uma cultura de desesperança e alienação, mas, pelo contrário, para um processo de emancipação que permita o surgimento de novas formas de reapropriação do mundo (LEFF, 2006).

\footnotetext{
${ }^{8}$ Esse ordenamento político da Educação Ambiental no Brasil encontra-se no sentido de implementá-la na perspectiva transdisciplinar, crítica e problematizadora, valorizando os saberes locais e tradicionais a fim de contribuir para a promoção social e ambiental, justa, democrática e de modo sustentável.
} 
É importante destacar que a educação, por si só, não resolve os problemas socioambientais existentes na sociedade contemporânea. Contudo, acredita-se, a partir de Freire (2005), que sem ela a sociedade não muda, pois não se mobilizarão possíveis transformações. Portanto, a mudança da racionalidade técnico-científica e economicista para a racionalidade socioambiental requer uma Educação Ambiental crítica e dialógica que seja praticada em uma interface com o diálogo de saberes provenientes da diversidade cultural, na qual o Brasil e o estado de Mato Grosso, embora tente implantar um só modo hegemônico de cultura, estão imbricados em virtude de diversos sujeitos históricos, línguas e diferentes cosmologias.

Outro ponto seria diferenciar o que se entende por Educação Ambiental e por que neste estudo estão associadas à sua concepção as palavras crítica e dialógica. A Educação Ambiental crítica e dialógica não é neutra, pauta-se na sustentabilidade que propõe um desenvolvimento que harmonize os objetivos sociais, ambientais, econômicos, éticos e co-participativos ${ }^{9}$ e não no desenvolvimento econômico técnico-científico, no qual prevalece a ideologia do progresso associada à negação e minimização das questões socioambientais em função das necessidades do capitalismo (JACOBI, 2005; SILVA, 2015; MUCENIECKS, 2016).

A Educação Ambiental crítica e dialógica, no contexto do capital local e global, não pode ser romantizada com o propósito de apenas ensinar os(as) educandos(as) a jogarem "lixos" nos lugares corretos ou a trabalharem com sustentabilidade apenas para reciclar objetos. Está a serviço maior, além dessas interpretações limitadoras, simplistas e não contextualizadas da realidade e da relação entre a sociedadenatureza. A partir da Educação Ambiental crítica e dialógica constata-se a necessidade de compreender o lugar que os sujeitos ocupam no espaço, as relações entre os homens com o território local-global; e como o modo de produção, que impera na sociedade urbana-industrial, articula-se para avançar cada vez mais nos corpos e mentes e na forma de relacionar-se com o meio ambiente.

Segundo Freire (2005), é por meio do diálogo de saberes que os sujeitos envolvidos nos processos educativos tornam-se críticos, reflexivos e interdependentes. Assim, o diálogo de saberes estabelecido por meio do encontro e enriquecimento mútuo do conhecimento científico e do conhecimento dos povos tradicionais, que é proveniente das experiências vivenciadas pelos sujeitos sociais, pode contribuir com as propostas da Educação Ambiental em uma perspectiva crítica e reflexiva, contextualizadora e integradora da realidade local com a totalidade das relações socioambientais.

Compreende-se que os conflitos socioambientais dessa região estão articulados ao desenvolvimento econômico correspondente à ideia de progresso e de dominação do homem sobre a natureza associado à degradação ambiental, por meio da qual desterritorializam os povos tradicionais do meio em que vivem e da sua relação com a terra e os destituem da prática social da construção do saber e do conhecimento. Nesse contexto, ocorre o que Silva (2015) afirma sobre a relação homem e natureza na perspectiva do capitalismo "à medida que a natureza é apropriada e instrumentalizada como mercadoria e propriedade privada, os saberes e os modos de vida tradicionais são esvaziados e desapropriados".

${ }^{9}$ Remonta aos princípios apresentados na Carta da Terra que orientam as ações coletivas e individuais para construção de uma sociedade sustentável global baseada no respeito pela natureza, nos direitos humanos universais, na justiça econômica e numa cultura da paz (MMA, 2005). 
O esvaziamento, apagamento das diversidades nos territórios mato-grossenses ocorre em virtude das estratégias políticas hegemônicas do capitalismo via operadores locais do agronegócio que transforma o território pluridiverso (biológica, social, cultural e economicamente) em um território homogêneo e alienado, região funcional que cumpre um papel na divisão internacional do trabalho (produtor de carne e de grãos), mas pouco serve às populações locais, gerando um processo de injustiça socioambiental, pois coloca essas populações à margem do processo de decisão sobre que tipo de desenvolvimento querem e/ou necessitam. Nesse sentido, ocorre o que Harvey (2006) denomina de acumulação por desapossamento, aplicada como forma contínua e histórica da acumulação primitiva de capital proposta por Marx.

A acumulação por desapossamento, no capitalismo contemporâneo de Harvey, remonta a alguns pressupostos práticos da acumulação primitiva: por meio da depredação, fraude e violência. 0 desapossamento é operado na estrutura social e política e sua proposição é essencialmente espoliadora. Portanto, o Estado exerce papel importante na operacionalização do capitalismo contemporâneo, exemplo disso são as políticas de integração nacional, colonizatórias e implantação de empreendimentos agropecuários, industriais e serviços que foram e, ainda são, implementadas e desenvolvidas sem considerar os direitos dos povos preexistentes em seus territórios, processo este que ocorreu no contexto amazônico norte mato-grossense.

Devido ao processo histórico e contínuo do capital em detrimento da classe trabalhadora, Harvey (2006) considera que a acumulação por desapossamento é aplicada por meio de um conjunto de mecanismos de opressão e exploração decorrentes da acumulação capitalista. A título de exemplificação, lembra-se que ocorrem os sistemas de crédito e capital financeiro, formação de políticas de negociação internacionais (OMC), biopirataria, mercantilização da natureza, da cultura, história e produção intelectual, proliferação da degradação ambiental na produção agrícola, privatização de bens públicos, garantias de trabalho no sentido de "cercamento dos bens comuns". Além desses:

mercantilização e privatização da terra e expulsão violenta de populações camponesas e indígenas, conversão de várias formas de direito em propriedades privadas exclusivas, supressão dos direitos aos bens comuns, transformação da força de trabalho em mercadoria e a supressão de formas de produção e consumo alternativos (como indígenas), processos que marcam os períodos colonial, neocolonial e imperial de apropriação de bens, inclusive reservas naturais, monetarização das trocas e da cobrança de impostos, mercado de escravos, usura, débito nacional e por fim sistema de crédito como meio de acumulação radical de acumulação primitiva (HARVEY, 2006).

O desapossamento na região centro-norte do Mato Grosso, bem como em outras partes da América, África, Ásia, tem ocorrido com a finalidade de negar os direitos das comunidades tradicionais, situação que passaram as comunidades indígenas, por exemplo, no processo de colonização dessa região. Para que isso ocorra, há necessidade do desmatamento civilizador, o que acarreta perda e redução da riqueza da sociobiodiversidade e completa insustentabilidade ecológica por meio da (erosão gen-ética), degradação dos solos (erosão) pela modificação/adulteração da cobertura vegetal nativa e uso intenso e agressivo via máquinas e componentes químicos, bem como sementes geneticamente modificadas, inserção de uma logística que atende aos negócios e não às populações (BRÜGGER, 2006). Além disso, outra fronteira de exploração é a formação de barragens para instalação de Usinas Hidrelétricas e Pequenas Centrais- 
Hidrelétricas previstas nas bacias dos principais rios do estado, como a Bacia do Rio Teles Pires ${ }^{10}$, os quais constituem exemplos dos impactos de grandes empreendimentos que influenciam o modo de vida, uso e apropriação do território e de seus recursos naturais, causando efeitos nefastos para a sociobiodiversidade.

Nas últimas décadas, o Brasil passou por reconfigurações para se inserir mundialmente como produtor de commodities a fim de atender as necessidades de potências mundiais como China e Europa, situação que tem aprofundado os problemas socioambientais locais. As análises dessa problemática não podem ficar restritas apenas ao seu contexto local, tendo em vista que no sociometabolismo do capital as relações produtivas possuem interconexões com o mercado global (LEHER, 2015); logo, os conflitos socioambientais que ocorrem no Brasil também podem ser vistos em outros países da América Latina, África, grande parte da Ásia, enfim nos países que constituem o Sul Global.

A produção para manutenção do sociometabolismo do capital, na fase da mundialização do capital, conforme os estudos de Harvey (2009), aprofunda as desigualdades socioambientais, concentra riqueza nas mãos de uma minoria que, além de se apropriar dos territórios, também os faz na arena política, dificultando as lutas das populações excluídas e marginalizadas que não conseguem se adequar a essa demanda internacional senão por meio da sua expropriação e venda de sua força de trabalho. Assim, identifica-se a questão socioambiental no centro das contradições do mundo moderno, afinal a ideia de progresso e desenvolvimento é sinônimo de dominação da natureza de forma globalizada.

Nesse sentido, a Educação Ambiental está situada em um contexto mais amplo e complexo, ainda em construção, mas que se orienta para a busca de emancipação e cidadania. Segundo as formulações de Jacobi (2005) e Costa e Acioly (2017), por meio da Educação Ambiental deve-se buscar a solidariedade, igualdade, respeito às diferenças por formas de atuação democráticas, interativas e dialógicas. Trata-se, ainda, de uma educação que permita - a partir da problematização do real - que o indivíduo exerça seus direitos quando das escolhas e decisões políticas que digam respeito à conservação do ambiente, justiça social, segurança alimentar, garantindo a sua dignidade e dos povos futuro na totalidade socioambiental.

Para materializar esta proposta de Educação Ambiental, seria necessário mobilizar uma série de mudanças institucionais e epistêmicas em torno do diálogo de saberes, oriundos da diversidade cultural, reconhecendo que a ciência ambiental pode ser produzida também pelos saberes tradicionais que foram historicamente subjugados pelo conhecimento científico moderno-ocidental. O mundo é pluridiverso, segundo Escobar (2016), por que então continuar a perpetuar um modelo homogêneo que não inclui, apenas exclui e apaga a beleza e a riqueza dos povos e conhecimentos produzidos por meio das vivências intrínsecas à natureza?

Sobre a homogeneização, monocultura e pensamento único, Tiezzi e Marchettini (2006) consideram que esses tópicos seguem a lógica da globalização e da destruição da diversidade cultural e biológica. Esse processo produz o "pensamento único que leva à morte térmica até a destruição final e, da mesma forma

\footnotetext{
${ }^{10}$ A Bacia do Rio Teles Pires localiza-se na Bacia Amazônica, tem área total de aproximadamente $142.000 \mathrm{~km}^{2}$, incluindo estados de Mato Grosso e Pará, abrange 33 municípios. A foz do Rio Teles Pires localiza-se no extremo norte do Estado de Mato Grosso, onde ocorre a confluência com o Rio Juruena, formando o Rio Tapajós, o qual tem sua foz no Rio Amazonas. Para efeitos de estudos e planejamento para Inventário Hidroelétrico, foi dividida em três sub-bacias: Baixo, Médio e Alto Teles Pires (EMPRESA DE PESQUISA ENERGÉTICA, 2009).
} 
um país, uma nação que faz o seu próprio isolamento, rejeição da contaminação cultural, realocação em posições conservacionistas fundamentalistas, um dogma político, também terá o mesmo fim".

Portanto, a Educação Ambiental que se defende não é simplista, apenas ensinando boas condutas para reduzir, reutilizar e reciclar, como muitas pessoas pensam, pois essas atitudes, embora benéficas, são incipientes diante da complexidade socioambiental e como espaço de resistência e construção para uma nova racionalidade que articule natureza, técnica e cultura em suas múltiplas e interconexas possibilidades. Segundo Costa e Accioly (2017), a Educação Ambiental tem "um duplo papel histórico: como ferramenta para o exercício da hegemonia por parte das frações dominantes e como instrumento de luta a ser apropriado pela classe trabalhadora em seu movimento de libertação".

Nesse sentido, a Educação Ambiental deve propor reflexões sobre a questão socioambiental, construindo uma racionalidade inscrita no empoderamento dos povos do Sul Global sobre seus direitos à vida e aos espaços onde constituem suas existências. Assim, a partir das considerações de Leff (2006):

\begin{abstract}
A questão ambiental não só incide sobre o problema da distribuição do poder e da renda, da propriedade formal da terra e dos meios de produção, e da incorporação da população aos mecanismos de participação dos órgãos corporativos da vida econômica e política. As demandas ambientais discutem a questão da participação democrática da sociedade na gestão de seus recursos atuais e potenciais, bem como no processo de tomada de decisões para a escolha de novos estilos de vida e a construção de futuros possíveis sob os princípios de independência política, equidade social, diversidade étnica, sustentabilidade ecológica, equilíbrio regional e autonomia cultural.
\end{abstract}

Assim, o saber ambiental que se pretende compreender no território centro-norte mato-grossense não é homogêneo, fechado e acabado, mas heterogêneo, aberto e possui diferentes territorialidades em suas mais variadas relações com a natureza. É ainda constituído por diversas formações ideológicas e de múltiplas práticas sociais, tais como o saber camponês, indígena, o saber acadêmico e, inclusive, o saber dos produtores rurais que manifestam nesse território o discurso da globalização econômica e hegemônica. A coexistência entre diferentes sujeitos sociais e de seus saberes no território centro-norte mato-grossense necessita estabelecer um diálogo para construir novas racionalidades em especial para sustentabilidade desta e das futuras gerações no meio ambiente. Afinal, segundo Santos, Meneses e Nunes (2004), o diálogo entre saberes não é constituído pela valorização de um em detrimento de outro saber, mas na relação dialógica entre os diferentes conhecimentos, que podem caminhar para a construção da sustentabilidade e formação de sociedades mais justas.

\title{
CONSIDERAÇÕES FINAIS
}

A Educação Ambiental, nas últimas décadas dos séculos XX e XXI, tem sido expressa nos espaços do ensino formal e em outros espaços sociais, abordando as suas problemáticas em função da atual crise ecológica e das suas consequências para a biodiversidade no planeta. Compreende-se que, no sociometabolismo do capital, a ação do homem sobre a natureza por meio do trabalho sofreu rupturas que causaram desequilíbrios no processo histórico da relação homem-natureza por meio da transformação do meio ambiente em mercadoria. Nesse sentido, a ciência moderna contribuiu para o acirramento dessa crise 
em função dos interesses mercantis e privados que apartaram o homem da natureza sob a justificativa de dominação e mercantilização de seus recursos naturais.

Tendo como base a análise material e histórica dessa sociedade desigual, observa-se que, no processo de geração de lucro, esse sistema destrói e desperdiça recursos naturais e postula uma fronteira abissal entre populações que detém saberes construídos a partir da coevolução entre sociedades e seus ambientes naturais. Além disso, a fronteira que se forma não é apenas territorial, mas epistêmica e ontológica porque potencializa o fosso entre pobreza e riqueza e gera graves conflitos e injustiças socioambientais, como foram e são, ainda, realizados em todo contexto da Amazônia Legal, no qual a região centro-norte mato-grossense se insere.

Identifica-se neste território a fronteira abissal epistemológica e ontológica por meio da grilagem de terras, da exploração madeireira, do desmatamento, do desflorestamento, da criação extensiva de gado e da produção de commodities, da entrada de alta tecnologia, da movimentação de fauna, flora e de humanos em um território ricamente sociobiodiverso que tem sido colocado abaixo da linha abissal por meio da expansão do capitalismo global na fronteira agrícola, em detrimento das populações locais.

Historicamente, esse território foi se transformando e sendo conhecido pela exploração da natureza em função do progresso, da modernização e da sobreposição de monoculturas produtivas e de um saber hegemônico voltados para expansão do capital na Amazônia norte mato-grossense. Assim, constata-se a questão socioambiental local-global no centro das contradições do mundo moderno, afinadas com a ideia de progresso e de desenvolvimento como sinônimo de dominação de povos e da natureza de forma local, porém alinhada ao modelo de exploração globalizada.

A complexidade da crise socioambiental local do contexto analisado foi desenvolvida a partir de um processo de uso e ocupação do território que, embora seja recente, remonta aos moldes de colonização moderno-eurocêntrico do século XVI, seguindo a lógica da acumulação por desapossamento, aplicando processos predatórios em diferentes culturas e na natureza em função da ampliação do espaço geográfico capitalista. Essa expansão ocorre de modo desigual, revelando as profundas alterações socioambientais por meio da conquista de territórios, da sobreposição de saberes e de populações e da transformação ecossistêmica para efeitos de acumulação privada do capital. Esse processo gerou a crise socioambiental local, articulada à crise global, a partir de uma racionalidade que mercantiliza as relações humanas e, sobretudo, a relação entre o homem e o meio ambiente que é norteada pela dominação, colonização do espaço, das mentes, dos corpos e da natureza, como lembra Shiva (2003).

Assim, quanto mais se amplia a compreensão da realidade concreta, dialética e síntese de múltiplas determinações, mais se sente a necessidade de explicar que no território centro-norte de Mato Grosso não existe apenas uma unidade epistêmica e ontológica, mas coexiste a diversidade cultural que tem condições, a partir de seus conhecimentos que coevoluíram com a natureza, de dialogar com os conhecimentos científicos a fim de buscar alternativas para construção de sociedades justas e sustentáveis do ponto de vista socioambiental e não apenas economicista. Portanto, questiona-se é possível, na materialidade do território 
centro-norte mato-grossense, frente à coexistência de diferentes sujeitos e saberes ambientais, efetivar o diálogo de saberes e culturas para a construção da racionalidade socioambiental.

Nesse sentido, a prática social e uma nova racionalidade socioambiental proposta por meio da Educação Ambiental crítica e dialógica no encontro com o diálogo de saberes e culturas pode engendrar novas relações de humanização dos homens e das mulheres com a natureza a partir do reconhecimento da diversidade cultural e epistêmica existente nos diversos territórios, pois existem outras formas de relação entre sociedade-natureza para além da relação antropocêntrica pautada na dominação e mercantilização, mas de cooperação ecologicamente e socialmente sustentável. A Educação Ambiental crítica, se aplicada no cenário da região centro-norte de Mato Grosso, pode ser caminho à visibilização do que foi histórica, epistemológica e ontologicamente negado, oculto e dominado, como os sistemas ecológicos, os povos indígenas, os trabalhadores explorados, os camponeses, os povos da floresta, bem como seus conhecimentos e modos de vida integrados à natureza. Esse contexto foi sobrepujado, desapossado em detrimento da satisfação da "vocação regional" estabelecida pelo capital, sendo o Estado e os operadores locais do capital os indutores do movimento de humanos, fauna e flora gerando a crise socioambiental local articulada à crise global.

\section{REFERÊNCIAS}

ALENTEJANO, P. Modernização da agricultura. In: CALDART, R. S.; PEREIRA, I. B.; ALENTEJANO, P.; FRIGOTTO, G.. Dicionário da educação do campo. Rio de Janeiro, São Paulo: Escola Politécnica de Saúde Joaquim Venâncio, Expressão Popular, 2012, p. 477-481.

ARANTES, A.; BAMPI, A. C. Normatização, regulação e alienação do território amazônico na produção de energia elétrica: o caso da UHECOLÍDER. In: SILVEIRA, R. L.; SOUZA, M. B.. Norma e território: contribuições multidisciplinares. Santa Cruz do Sul: EDUNISC, 2017.

BAMPI, A. C. Prefácio: elementos para entendimento das consequências da inserção e expansão do capitalismo na Amazônia. In: PICOLI, F. A violência e o poder de destruição do capital na Amazônia. Florianópolis: em Debate, 2012. p. 7-17.

BRASIL. Constituição (1988). Constituição da República Federativa do Brasil de 1988. Brasília, DF, 5 de outubro 1988.

BRASIL. Lei no 9.795, de 27 de abril de 1999. Dispõe sobre a educação ambiental, institui a Política Nacional de Educação Ambiental e dá outras providências. Brasília, DF, 27 de abril de 1999.

BRASIL. Decreto no 6.040, de 07 de fevereiro de 2007. Institui A Política Nacional de Desenvolvimento Sustentável dos Povos e Comunidades Tradicionais. Brasília, 07 de fevereiro de 2007.

BRÜGGER, P. O vôo da águia: reflexões sobre método, interdisciplinaridade e meio ambiente. Educar, Curitiba - PR, n. 27, p. 75-91, jan./jun. 2006
BUBLITZ, J. O recomeço na mata: notas para uma história ambiental da colonização alemã no Rio Grande do Sul. História Unisinos, São Leopoldo, v. 12, n. 3, p.207-218, 30 jan. 2008. DOI: http://dx.doi.org/10.4013/htu.20083.02

CASTRO, S. P. et al. A colonização oficial em Mato Grosso: a nata e a borra da sociedade. Cuiabá: EdUFMT, 2002.

CASTRO-GÓMEZ, S. Decolonizar la Universidad. La hybris del punto cero y el diálogo de saberes. In: CASTRO-GÓMEZ, S.; GROSFOGUEL, R.. El giro decolonial: reflexiones para una diversidad epistémica más allá del capitalismo global. Bogotá: Siglo del Hombre Editores, Instituto Pensar, 2007, p.79-91.

COSTA, C. A. S.; LOUREIRO, C. F. Educação ambiental crítica: uma leitura ancorada em Enrique Dussel e Paulo Freire. Revista Eletrônica Geoaraguaia, Barra do Garças-MT, v. 3, n. 2, p. 83-99, 2013.

COSTA, C. A. S.; ACCIOLY, I. A formação em educação ambiental crítica na periferia do capitalismo: contribuições marxistas. Revista Trabalho, Política e Sociedade, Rio de Janeiro, v. 2, n. 2, p.23-42, jan./jun. 2017.

DIEGUES, A. C.; ARRUDA, R. S. V. Saberes tradicionais e biodiversidade no Brasil. São Paulo: USP, 2001.

EMPRESA DE PESQUISA ENERGÉTICA. Avaliação ambiental integrada da bacia hidrográfica do rio Teles Pires. Relatório Final - Sumário Executivo. CONCREMAT, 2009.

ESCOBAR, A. Desde abajo, por la izquierda, y con la tierra. El pais: Contrapuntos, 2016. 
ESTADO DE MATO GROSSO. SECRETARIA DE ESTADO DE PLANEJAMENTO E COORDENAÇÃO. Regiões de planejamento de Mato Grosso: 2017. Cuiabá, 2017.

FLORIANI, D. Complexidade e epistemologia ambiental em processos socioculturais globais e locais. INTERthesis, Florianópolis, v. 07, n. 02, p. 45-64, jul./dez. 2010.

FREIRE, P. Pedagogia do oprimido. Rio de Janeiro: Paz e Terra, 2005.

JACOBI, P. R. Educação ambiental: o desafio da construção de um pensamento crítico, complexo e reflexivo. Educação e Pesquisa, São Paulo, v. 31, n. 2, p. 233-250, 2005.

JÚNIOR, S.C. C. T. Cidades na floresta: os "grandes objetos" como expressões do meio técnico-científico informacional no espaço amazônico. Revista IEB, n. 50, p. 113-138, mar./set. 2010.

HARVEY, D.. O "novo imperialismo": acumulação por desapossamento (Parte II). São Paulo: Revista Lutas Sociais, n.15/16, p. 21-34, 2006

HARVEY, D.. Condição pós-moderna. 18. ed., São Paulo: Edições Loyola. 2009.

\section{INSTITUTO BRASILEIRO DE GEOGRAFIA E ESTATÍSTICA.} Produção da pecuária municipal, vol. 39, 2011.

LEFF, E. Epistemologia ambiental. 4 ed. São Paulo: Cortez, 2006.

LEHER, R. A educação ambiental como crítica ao desenvolvimento sustentável: notas sobre o método. Pesquisa em Educação Ambiental, Departamento de Educação da Universidade Estadual Paulista - UNESP, v. 11, n. 2, p.10-23, 31 out. 2016. DOI: http://dx.doi.org/10.18675/2177-580x.vol11.n2.p10-23

MARTINS, J. S. Fronteira: a degradação do outro nos confins do humano. São Paulo: HUCITEC, 1997.

\section{MINISTÉRIO DO MEIO AMBIENTE. Programa nacional de educação ambiental (ProNEA). 3 ed. Brasília: Ministério do Meio Ambiente, 2005.}

MUCENIECKS, R. S. Políticas de educação e meio ambiente: o Brasil como articulador político no Mercosul. $236 \mathrm{f}$. Tese (Doutorado) - Programa de Pós-graduação em Educação, Universidade Estadual de Maringá, Maringá/PR, 2016.

OLIVEIRA, A. U. BR-163 Cuiabá-Santarém: geopolítica, grilagem, violência e mundialização. In: TORRES, $M$. Amazônia revelada: os descaminhos ao longo da BR-163. Brasília: CNPq, 2005, p. 67-184.

PORTO-GONÇALVES, C. W. Ambiente (meio ambiente). In: CALDART, R. S.; PEREIRA, I. B.; ALENTEJANO, P.; FRIGOTTO, G. (orgs.). Dicionário da Educação do Campo. Rio de Janeiro, São Paulo: Escola Politécnica de Saúde Joaquim Venâncio, Expressão Popular, 2012. p. 94-103.
PROPAGANDA EM REVISTA. Chega de lendas, vamos faturar! Anunciada pela SUDAM em 1970, 2015.

QUIJANO, A. Colonialidade do poder, eurocentrismo e América Latina. In: LANDER, E.. A colonialidade do saber eurocentrismo e ciências sociais: perspectivas latinoamericanas. Buenos Aires: CLACSO, 2005, p. 227-278.

SANTOS, B. S.; MENESES, M. P.; NUNES, J. A. Introdução: para ampliar o cânone da ciência: a diversidade epistemológica do mundo. In: SANTOS, B. S.. Semear outras soluções: os caminhos da biodiversidade e dos conhecimentos rivais. Porto: Afrontamento, 2004, p. 23-81.

SANTOS, B. S.; MENESES, M. P. Introducción. In: SANTOS, B. S.; MENESES, M. P.. Epistemologias del Sul (Perpesctivas). Madrid: Akal, 2014, p. 7-17.

SANTOS, B. S. S. Más allá del pensamiento abismal: de las líneas globales a una ecología de saberes. In: SANTOS, B.S.; MENESES, M. P.. Epistemologías del Sur (Perspectivas). Madrid: AKAL, 2014, 31-84.

SANTOS, M.; SILVEIRA, M. L. O Brasil: território e sociedade no início do século XXI. 18. ed. Rio de Janeiro: Record, 2014.

SAVIANI, D. Breves considerações sobre fontes para a história da educação. In: LOMBARDI, J. C.; NASCIMENTO, M. I. M.. Fontes, história e historiografia da educação. Campinas: Autores Associados/HISTEDBR; Curitiba: PUC-PR; Palmas: UNICS; Ponta Grossa: UEPG, 2004. p.3-12.

SILVA, A. T. R. A conservação da biodiversidade entre os saberes da tradição e a ciência. Estudos Avançados, São Paulo, v. 29, n. 83, p.233-259, abr. 2015. DOI: http://dx.doi.org/10.1590/s0103-40142015000100012

SILVEIRA, J.M.; DA SILVA, C. J.; SIMONI, J. Identificação e caracterização dos grupos sociais (stakeholders) no Sistema de Baías Chacororé - Sinhá Mariana. In: DA SILVA, C. J.; SIMONI, J.. Água, biodiversidade e cultura do Pantanal: estudos ecológicos e etnobiológicos no sistema de Baías Chacororé - Sinhá Mariana. Cáceres: UNEMAT, 2012, p. 181198.

SHIVA, V. Monoculturas da mente. São Paulo: Global, 2003.

TIEZZI, E.; MARCHETTINI, N. Conservazione della biodiversità e sviluppo. In: TURUS, G.; ALTOBRANDO, A. Biodifferenze. ESEDRA editrice, 2006, p. 1-9.

TOLEDO, V. M.; BARRERA-BASSOLS, N. A etnoecologia: uma ciência pós-normal que estuda as sabedorias tradicionais. Desenvolvimento e Meio Ambiente, Universidade Federal do Paraná, n. 20, p. 31-45, 2009.

TOZONI-REIS, M. F. C. Educação ambiental: natureza, razão e história. 2 ed. Campinas: Autores Associados, 2008.

VELHO, O. G. Capitalismo autoritário e campesinato: um estudo comparativo a partir da fronteira em movimento. Rio de Janeiro: Centro Edelstein de Pesquisas Sociais, 2009.

A CBPC - Companhia Brasileira de Produção Científica (CNPJ: 11.221.422/0001-03) detém os direitos materiais desta publicação. Os direitos referem-se à publicação do trabalho em qualquer parte do mundo, incluindo os direitos às renovações, expansões e disseminações da contribuição, bem como outros direitos subsidiários. Todos os trabalhos publicados eletronicamente poderão posteriormente ser publicados em coletâneas impressas sob coordenação da Sustenere Publishing, da Companhia Brasileira de Produção Científica e seus parceiros autorizados. Os (as) autores (as) preservam os direitos autorais, mas não têm permissão para a publicação da contribuição em outro meio, impresso ou digital, em português ou em tradução. 
